\title{
Takhrij Fikih dan Permasalahan Kontemporer
}

\author{
Meirison \\ Universitas Islam Negeri (UIN) Imam Bonjol Padang \\ meirison@uinib.ac.id \\ Desmadi Saharuddin \\ Universitas Islam Negeri (UIN) Syarif Hidayatullah Jakarta \\ desmadi.saharuddin@uinjkt.ac.id \\ Rosdialena \\ Universitas Islam Negeri (UIN) Imam Bonjol Padang \\ rosdialena@gmail.com
}

\begin{tabular}{l|l|l}
\hline Received: 18 Februari 2020 & Revised: 20 Maret 2020 & Approved: 24 April 2020 \\
\hline
\end{tabular}

\begin{abstract}
This paper aims to describe Takbrij as a medium for understanding the general rules established by imams that are built on the fiqh by induction and analyzing specific problems (furu' fiqbiyab), this is what the takbrij usbul means for furu'. Takbrij also means to resolve differences furu' fiqbiyah with the usbuliyah rules originating from the imams. It is expected to find a law that does not have the proposition shara' by returning it to the rules and usbul. With a literature study and comparative approach to descriptive analysis, it is found that fiqh takbrij is also used to recognize the law that comes from a priest in a problem that has no text. Its can be made by comparing it with the same furu' problem with the texts (qiyas), or comparing it with the understanding of Imam's texts or its generality. This is the furu' tabkrij 'on furu'. Takbrij fiqh can be applied to contemporary problems such as loading and unloading insurance, inflation, copyright, and syariah laws in contemporary matters. The development of takbrij figh is dependent on the interaction of theory and practice in the existing field to produce solutions to contemporary problems.
\end{abstract}

Keywords: Problems, Takbrij Fikih, Contemporary

\begin{abstract}
Abstrak
Tulisan ini bertujuan untuk memaparkan takbrij sebagai media untuk memahami kaidah umum yang ditetapkan oleh para imam yang dibangun di atas furu' fikih dengan cara induksi dan menganalisis permasalahan khusus (furu' fiqhiyah), inilah yang dimaksudkan takbrij ushul atas furu'
\end{abstract}


Takhrij juga bermakna menyelesaikan perbedaan furu' fiqhiyah dengan kaidah ushuliyah yang berasal dari para imam. Diharapkan dapat menemukan hukum yang tidak ada dalil syara'nya dengan cara mengembalikannya kepada kaidah dan ushul. Penelitian ini merupakan studi kepustakaan dengan pendekatan komparatif analisis deskriptif. Penelitian ini menemukan bahwa takhrij fikih juga digunakan untuk mengenal hukum yang berasal dari imam dalam masalah yang tidak ada nasnya dengan membandingkannya dengan permasalahan furu' yang sama yang ada nashnya (qiyas), atau membandingkannya dengan pemahaman nash-nash imam atau generalitasnya. Ini adalah takhrij furu' atas furu'. Takhrij fikih ini dapat diterapkan pada permasalahan kontemporer seperti asuransi bongkar muat, inflasi, hak cipta, dan hukum-hukum syara' dalam permasalahan kontemporer. Perkembangan takhrij fikih ini bergantung kepada interaksi teori dan praktik di lapangan yang ada sehingga membuahkan solusi bagi masalah kontemporer.

Kata Kunci: Permasalahan, Takhrij Fikih, , Kontemporer

\section{Pendahuluan}

Perubahan adalah sifat alam yang selalu ada, khususnya di bidang takhrij fikih yang memiliki banyak faedah yang harus kembali dilakukan tela'ah untuk menyelesaikan permasalahan-permasalahan baru baik yang dihadapi oleh umat Islam dalam keseharian secara individu, kelompok dan negara di berbagai bidang sosial budaya, politik, ekonomi dan keamanan. Yang terpenting dalam pembahasan ini adalah memunculkan bahwa Syari'at Islam mempunyai solusi sejalan dengan perkembangan zaman bagi mukallaf dalam segala dimensi ruang dan waktu. Penyelesaian secara syar'i akan memberikan dampak positif terhadap kejiwaan seorang muslim yang mendapatkan penyelesaian yang Islami dan terbebas dari beban moril yang membelenggu jiwa seorang muslim.

Syari'at Islam mempunyai banyak instrumen dalam menyelesaikan banyak perkara-perkara kontemporer. Warisan Figh dan kaidah serta pola-pola ijtihad ulama masa lalu sangat membantu dalam memberikan solusi hukum yang dihadapi oleh umat Islam, yang diselaraskan dengan maqashid syari'ab dan dibantu oleh Qawaid al-Lughawiyah dalam memahami naskah-naskah dan teks-teks syar'i. Termasuk takbrij fikih yang merupakan bias dari Alquran, Hadits, Ijma', Qiyas, Istihsan, Istishab, Sad a-Zair'ah, Qaulu as-Sababi, dan Syar'u man Qablana. Usahausaha para ulama seperti Bahusain telah menampakkan hasil dengan lahirnya buku-buku tentang takhrij fikih. Pada abad ke 4 hijriyah. Ibnu Khaldun mengatakan, mazhab yang empat berdiri di atas ushul al-millah yang tidak terlepas dari khilafiyah bagi para pengikut yang berpegang kepada hukumhukumnya yang berasal dari nusus syar'iyah dan ushul fiqh. Para ulama melakukan perdebatan dalam melakukan justifikasi terhadap mazhab mereka.

Dalam perdebatan ini didapatkan dalil-dalil dan landasan pemikiran para imam dan pengikut mazhab masing-masing. Hal ini sangat penting untuk 
diketahui agar para pemikir dan ulama dapat mengetahui kaidah dan metode yang dilalui oleh para imam mazhab serta para pengikutnya untuk melakukan istinbath hukum. Para pengikut mazhab mentakhrij pendapat-pendapat imamimam bereka beserta dalil-dalil yang digunakannya. Takbrij terhadap pendapat para imam telah nampak jelas dalam karya-karya Muhammad bin Hasan dan Abu Yusuf dari mazhab Hanafi, dan Abdurrahman bin Qasim, Ashub dan Sahnun. Tidak hanya sampai di situ para ulama Mazhab Syafi'iy juga melakukan takhrij tersebut seperti ar-Rabi' bin Sulaiman dan Abdullah bin Imam Ahmad bin Hanbal, al-Mazuri dan para ulama mazhab Hanbali lainnya. Hasil pemikiran dari takhrij ini disusun oleh ad-Dabusi (wafat $430 \mathrm{H}$ ) yang bernama Nazar atTa'sis. Seabad setelah itu disusunlah buku yang terperinci yang berjudul Takbrij al-Furu' 'ala al-Usbul yang disusun oleh Syihabuddiin Mahmud bin Ahmad alZanjani as-Syafi'iy (wafat $656 \mathrm{H}$ ). Dengan mempelajari literatur ini secara komparatif penulis melakukan analisis konten dan menjelaskan keterkaitannya dengan permasalahan kontemporer. Sehingga pendapat imam mazhab masih dapat berlaku dalam menghadapi permasalahan kontemporer sesuai dengan kaidah mazhab.

\section{Pembahasan}

Sesuai dengan tata bahasa (kaidah lughawn), kata takhrij adalah bentuk mashdar dari kata خرب - خang artinya adalah mengeluarkan, memisahkan dari bagian atau kelompok, arti lainnya adalah penghasilan yang mempunyai makna konotasi menghasilkan makna majazi dan hisi. Secara

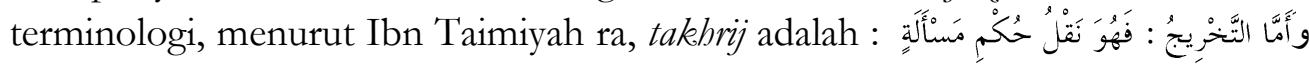

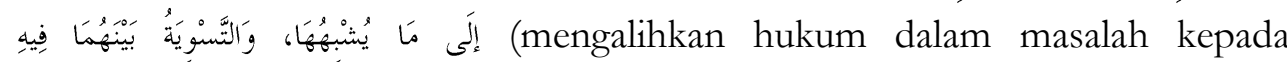
permasalahan yang mempunyai kesamaan dalam beberapa aspek sehingga dapat disamakan hukumnya. ${ }^{1}$ Terminologi ini juga dinyatakan oleh al-Mardawi ${ }^{2}$ dan Ibn Badran. ${ }^{3}$ Ibn Farhun ${ }^{4}$ mereka menyatakan secara istilah, tentang takbrij adalah إستخراج حكم مسألة من مسألة منصوصة (menghasilkan produk hukum suatu masalah dari permasalahan yang status hukumnya tertera dalam nash). al-Syekh Alawi al-Saqaf berpendapat, أن التخريج ان ينقل فقهاء المذهب الحكم من نص إمامهم ف صورة إلى

${ }^{1}$ Ibnu Taiymiyah Ahmad Ibn Abdul Hiim, Al-Musawwidah, Mubaqqiq: Mubammad Mubyi al-Din Abd al-Hamid (Beirut: Dar al-Kutub, 1987), h. 533.

${ }^{2}$ Syaikh Wali Allah al-Dahlawi Syaikh Wali Allah ad-Dahlawi, Al-Inshaf Fi Bayan Asbab al-Ikhtilaf, Ditahqiq Oleh Abd al-Fattah Abu Ghadah, vol. 2 (Beirut, Lebanon: Dar al-Kutub Ilmiyah, 1987), h. 6.

3 Abd al-Qadir ibn Ahmad ibn Badran Abd al-Qadir ibn Ahmad ibn Badran, al-Madkh ila Maz̧hab al-Imam Ahmad (Kairo: Maktabah Ibnu Taimiyah, 1977), h. 56.

${ }^{4}$ Ibnu Farhun al-Maliki Ibnu Farhun al-Maliki, Kasyf Al-Naqab al- Hajib Fi Mushthab Ibn al-Hajib, Ditahqiq Oleh Hamzah Abu Faris Dan Abd al-Salam al-Syarif (Rabath: Dar al-Gharb alIslami, 1990), h. 56. 
صورة مشاكية takhrij adalah aksi fuqaba' mazhab menyamakan hukum dari pendapat imam mereka dengan satu bentuk permasalahan baru yang serupa. ${ }^{5}$ Definisi yang

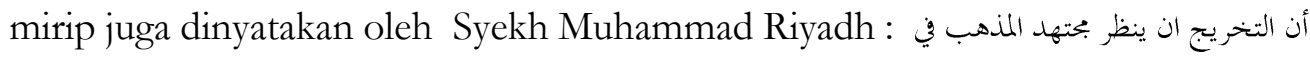
مسألة غير منصوص عليها فيقيسها على مسألة منصوص عليها في المذهب (takhrij adalah seorang mujtabid mazhab melakukan tela'ah terhadap sebuah permasalahan yang tidak mempunyai nash lalu ia mengqiyaskannya kepada permasalahan mempunyai nash). ${ }^{6}$

Dapat dipahami dari beberapa terminologi di atas, seperti yang dipaparkan oleh Syekh Yaqub al-Ba Husain dalam kitab karyanya yang berjudul al-Takbrij 'inda al-Fuqoha' wa al-Ushuliyin,' dapat ditangkap gambaran dari definisidefinis tersebut :

1. Takbrij akan menghantarkan kepada ushul dan qa'idah yang dibangun para imam sebagai landasan yang mempunyai hubungan interaksi dengan hukumhukum dalam masalah fikih yang dinukilkan dari mereka.

2. Secara umum, takhrij mengembalikan semua perbedaan fikih kepada qa'idah ushul.

3. Kadangkala takbrij sesuai dengan pemakaiannya di kalangan fuqaba', yang berarti interprestasi nash yang menghasilkan hukum terbatas (al-istinbath almuqayyad), maksudnya adalah menjelaskan pendapat imam dalam masalahmasalah parsial yang tidak ada nashnya dan mengaitkannya dengan permasalahan yang mirip dengannya, atau dengan mengukurnya dengan menggunakan suatu kaidah tertentu dalam mazhab.

4. Adakalanya fuqaha' mengembangkan makna takhrij yang mencakup makna penalaran illat (al-ta'li), atau memproyeksikan pendapat-pendapat yang dikutip dari para imam dan menjelaskan sumber pendapatnya dengan cara menggali illat hukum yang telah ditetapkan oleh imam sehingga dapat digunakan untuk melakukan interpretasi terhadap permasalahan yang baru.

Dapat disimpulkan dari penggunaan istilah takhrij oleh para fuqaha' dan ahli ushul fikih sebagai berikut :

1. Mentakhrij ushul atas/dari furu'. Mentakhrij furu' atas ushul dengan metode induksi dilakukan analisa untuk sampai kepada kesimpulan umum. Ini adalah metode Hanafiyah dan metode para ahli Ushul dalam menyusun karya-karya mereka. Contohnya menurut Malikiyah yang mentakhrij pendapat imam Malik yang mengatakan "al-amr lil faur" (perintah disegerakan), walaupun

\footnotetext{
1404), h. 77.

${ }^{6}$ Muhammad Riyadh Muhammad Riyadh, Ushul Al-Fatwa Wa al-Qadha' Fi al-Mazhab alMaliki (Maroko: Matba'ah al-Najah, 1416), h. 577.

${ }^{7}$ Syaikh Ya'qub al-Ba Husain Syaikh Ya'qub al-Ba Husain, Al-Takhrij Inda al-Fuqoha' Wa al-Ushuliyin (Riyadh: Maktabah al-Rusyd, 1414), h. 12-13.
}

${ }^{5}$ Alawi al-Saqaf Alawi al-Saqaf, Al-Fawaid al-Makiyah, I (Riyadh: Maktabah al-Rusyd, 
imam tidak menjelaskan hal tersebut pendapat tersebut tetap dinisbahkan kepada mazhabnya karena kaidah yang digunakan adalah kaidah yang disepakati oleh Imam, maka konsekuensinya naik haji adalah perkara yang harus disegerakan.

2. Takbrij Furu' ala al-Ushul. Pendapat yang ditakhrij dari nash Imam Mazhab, berdasarkan kaidah dan illat-illat yang dipakai oleh para imam serta berusaha memecahkan atau memperkecil ruang lingkup khilafiyah dan dapat menemukan keabsahannya.

3. Takbrij Furu' atas Furu', hal ini dilakukan oleh pengikut para imam, yang dinukilkan darinya permasalahan yang terbatas yang kadangkala terdapat permasalahan yang belum dibahas, kemudian mereka mentakhrij furu' yang lain. Sebagai contoh ditakhrijkan dari Imam Ahmad bahwa tartib (berurutan dalam berwudhu tidak wajib, sedangkan imam Ahmad tidak pernah mengatakan hal tersebut akan tetapi para pengikutnya mentakhrij dengan cara qiyas. Mereka menukilkan dari Imam Ahmad bahwa berurutan dalam berkumur-kumur dan istinsaq tidak wajib maka mereka menqiaskannya terhadap seluruh anggota wudhu' lainnya seperti tangan dan kaki.

4. Takbrij al-ubsul ala usbul, mentakhrij Ushul Fiqhiyah atas Ushuluddin dan yang kedua adalah mentakhrij kaidah ushubuliyah dari kaidah ushuluddin. Sebagai contoh Syi'ah Rafidah. Mereka berpendapat bahwa para imam ma'sum (terbebas dari dosa), maka segala perkataannya dapat dipercaya. Mereka tidak menjadikan hadits ahad sebagai landasan dalam aqidah karena mereka lebih mengemukakan akal dari naqal.

\section{Pembagian Takhrij Menurut Ulama Kontemporer}

Seperti yang telah dipaparkan sebelumnya takhrij dapat dibagi tiga, yaitu melakukan takbrij ushul dari furu', takbrij furu' atas ushul dan takbrij furu' dari furu'. Dr. Saad al-Syatari menambahkan jenis yang keempat dalam takhrij, yaitu melakukan takhrij ushul atas ushul. ${ }^{8} \mathrm{Hal}$ ini disebabkan sebagian kaidah ushul dilandaskan pada kaidah ushul yang lainnya yang mengikuti dan menjadi cabangnya. Pembagiannya adalah:

1. Mentakhrij ushul dari furu'.

Di antara bentuk takhrij adalah adanya interaksi antara ushul dan kaidah yang berasal dari para imam secara induktif dan mengikuti cabang-cabang fiqh yang diriwayatkan dari mereka, menjelaskan illat-illat yang terkait dengannya.

Sebagai contoh dari takbrij ini adalah apa yang dikatakan oleh al-Imam Abu Ya'la al-Farra' ra. dalam kitabnya yang berjudul al-Uddah yang dianggap

\footnotetext{
${ }^{8}$ Sa'ad al-Syatari Sa'ad al-Syatari, Al-Takhrij Baina al-Usbul Wa al-Furu (Kairo: Dar al-Hadits, 1989), h. 144-145.
} 
sebagai acuan kitab-kitab ushul dalam mazhab Hanbaliyah. Imam Abu Ya'la sangat terdorong dalam menjelaskan pendapat Imam Ahmad tentang permasalahan ushul dan mengungkapkannya dari riwayat-riwayat yang diterima dari sang imam, lalu mengaitkan pendapat itu kepada imam Ahmad karena ia mentakhrij sesuai dengan kaidah sang imam.

Bentuk takhrij ini memiliki beberapa faedah yang dapat dipetik oleh peneliti masalah kontemporer, diantaranya :

a. Adanya hubungan interaksi ilmu ini dengan kaidah-kaidah para imam, membuat para mujtahid yang menghadapi permasalahan kontemporer terbantu dalam mentarjih pendapat-pendapat dan memilih yang rajih atau yang terkuat berdasarkan kaidah tersebut.

b. Ilmu ini dapat dijadikan alat untuk membantu mengetahui korelasi yang terdapat antara furu' fiqh illat dapat diteliti dan dijelaskan dan diselaraskan dengan hukum yang ada pada furu', oleh karena itu terciptalah pemahaman yang konkret serta dapat menyesuaikan furu' yang diriwayatkan dari para imam kepada ushulnya.

c. Dengan adanya ilmu ini seorang alim dapat menarik kesimpulan dengan mentakhrij masalah-masalah dan cabang-cabang yang tidak mempunyai nashnya dari kejadian dan kasus terbaru sejalan dengan kaidah yang ditakhrij atau menemukan pendapat yang lebih muktamad.

d. Takhrij ini memperkenalkan kepada mujtahid sumber dan rujukan ulama dalam istinbath dan ushul ijtihadnya yang membantunya dalam memahami sebab-sebab perbedaan pendapat Fuqoha'.

2. Mentakhrij furu' dari ushul

Seperti yang telah di isyaratkan munculnya ilmu takbrij fikih sebagai sebuah disiplin ilmu yang berdiri sendiri pada pertengahan abad ke empat Hijriyah. Sejalan dengan maraknya perdebatan antara para pengikut mazhab fikih yang didorong oleh keinginan yang kuat untuk mencari landasan dari pendapat yang dikeluarkan oleh para imam mereka. ${ }^{9}$ Landasan atau ushul tersebut dijadikan batu loncatan untuk menetapkan kebenaran furu' yang dibangun di atas dasar ilmiah yang benar. Penyebab pertikaian pendapat tersebut dapat membantu untuk mencari keterkaitan antara furu' fikih yang beragam dan antara furu' dan usbul yang telah dijadikan dasar dari furu' itu sendiri. Hal ini dapat memperkuat kemampuan fikih dan pemahaman serta kemampuan melakukan

${ }^{9}$ Syekh Usman ibn Muhammad al-Ahdhari Syausyan telah mengarang sebuah kitab sistematis untuk memunculkan ilmu ini, yang dia beri nama "Takbrij al-Furu' ala al-UshuP', sebuah abstarksi risalah lengkap yang diajukannya ke Fakultas Syariah Universitas Islam Muhammad ibn Saud, untuk mendapatkan gelar magister tahun $1415 \mathrm{H}$. 
istinbath hukum. Furu' dapat dirunut kembali secara sistematis kepada usulnya. Permasalahan kontemporer dapat dianalisis dengan benar setelah ushul dari para imam dapat di tinjau ulang dengan benar

Imam al-Zanjani berkata: "permasalahan furu' akan dapat dianalisis dengan jelas yang mana semuanya berasal dari ushul yang benar, proses istinbath tidak akan dapat dipahami apabila hubungan antara hukum furu' dan ushul-nya tidak bisa dipindai dengan benar dan jelas. Seorang alim tidak memiliki peluang atau tidak mungkin sama sekali menemukan cabangnya. Sebab masalah-masalah furu' berdasarkan usbul mempunyai cabang yang sangat banyak dan setelah sampai kepadanya ushul yang diketahui berdasarkan penerapannya terhadap kasus-kaasus di lapangan secara beraturan. Barang siapa yang tidak mengetahui ushul dan kasus-kasusnya maka ia tidak akan mendapatkan ilmunya. ${ }^{10}$

Dr. Yakub al-Ba Husain mendefinisikan takhrij macam ini sebagai: "ilmu yang membahas tentang illat-illat atau sumber hukum syara' untuk mengembalikan furu' kepadanya sebagai penjelasan sebab-sebab pertikaian pendapat atau untuk menjelaskan hukum yang tidak ada nash (dalil/keterangan) dari para imam dengan memasukkannya (furu'/perkara) ke dalam kaidah dan usbul mereka". Sehingga pendapat tersebut atau hukumnya bisa dinisbahkan kepada mazhab dan imam. Usman ibn Muhammad al-Ahdhari bin Syausyan memberikan definisi: "Ilmu yang menjelaskan penerapan kaidah ushul dalam mengistinbathkan hukum syara' yang praktis dari dalil-dalil yang tafsili (terperinci)".

Ilmu takbrij furu' di atas ushul mencakup sebagian penelitian dan masalahmasalah yang tidak keluar dari hakikat ilmu fiqh dan ushul serta bentuk korelasi antara keduanya, maka diantara masalah yang tercakup dalam ilmu ini antara lain : ${ }^{11}$

a. Kaidah yang diperdebatkan keabsahannya (kesahihan) strukturnya dan legalitas pemakaian kaidah tersebut dalam penetapan hukum furu'.

b. Cara mentakhrij dan menistinbathkan hukum-hukum syara' dari dalil-dalilnya, terutama dari dalil yang diperselisihkan oleh para imam mazhab.

c. Persyaratan bagi seorang mukharij yang mentakhrij nushus para imam dan kaidah-kaidah mereka

d. Penyebab iktilaf para fuqoba'

e. Pemaparan yang berhubungan dengan para fuqaba' yang mentakhrij hukum memakai kaidah para imam beserta persyaratan yang wajib dipenuhi. n.d.), h.166.

${ }^{10}$ Sulaiman Majid Sulaiman Majid, Takbrij Furu' Ala al-Usbul (Kairo: Maktabah Wafa,

${ }^{11}$ Sulaiman Majid, h. 167-68. 
f. Penjelasan tentang hukum dan furu' fikih dalam tinjauan pengungkapan hubungan antara keduanya dan menyelaraskannya dengan ushul imam atau ushul orang-orang yang mentakhrij yang telah menisbahkannya kepada imam mereka.

Faedah yang didapatkan adalah mengenal sumber rujukan para imam dalam menghasilkan hukum sebuah perkara dan juga mengenal penyebab terjadinya perbedaan pendapat diantara mereka dalam kasus yang sama dan hukum yang berbeda. Buah dari ilmu ini adalah mentakhrij pendapat para imam berdasarkan kaidah dan ushul yang tidak terdapat dalamnya nash. Takhrij tidak akan bisa dilakukan tanpa mengetahui sumbernya yaitu naskah-naskah yang berisikan teks dari para imam serta kaidah yang digunakan oleh para imam itu sendiri dalam memunculkan sebuah hukum (isthinbat hukum). Hal ini akan sangat bermanfaat dalam istinbath hukum kontemporer diantaranya:

a. Ilmu menambah penguasaan terhadap fikih dan melatih pelajar dalam mengistinbatkan, mentarjih dan mengembangkan permasalahan yang disesuaikan dengan dalil-dalil yang didapatkannya.

b. Ilmu ini memungkinkan seorang faqih memahami secara mendalam apa yang di pelajarinya dan ditelitinya dalam kitab fikih.

c. Ilmu ini menghasilkan ilmu ushul dari sisi teoritisnya yang didapatkan dari lapangan secara aplikatif praktis sebagai buah yang muncul dari kaidah-kaidah ushul bahkan juga kaidah-kaidah fikih.

d. Ilmu ini dapat sebagai acuan peneliti dalam menghadapi permasalahan kontemporer dalam memutuskan perkara syar'i. Hasil keputusan hukum dalam menghadapi berbagai perkara dapat saja berbeda yang bergantung kepada metode istinbath dan kasus yang dihadapi oleh para fuqaha' dalam furu' yang mereka istinbathkan. Hal ini akan menghasilkan hukum-hukum fikih yang beragam.

e. Diantara manfaat takhrij adalah menyokong pendapat mujtahid dalam memunculkan hukum permasalahan kontemporer yang berkesinambungan dan akan memperkaya metode yang dipakai oleh para fuqaha'.

3. Mentakhrij furu' atas furu'

Hukum fikih dibangun diatas kaidah dan $u s h u l$ yang berbeda dan unsurunsur lain seperti kaidah nahwu dan lughawiyah serta ketetapan-ketetapan yang ada di dalamnya seperti yang dilakukan oleh al-Asnawi $(772 \mathrm{H})$ dalam bukunya yang berjudul al-Kawkeab ad-Durri fi Takhrij al-Furu' al-Fiqbiyah 'ala Masail anNabwiyah). Pendapat para imam dinukilkan oleh para pengikutnya yang menghasilkan cabang- cabang fikih (furu), ijtihad dan fatwa yang terkait dengan hukum-hukum peristiwa yang belum ditemukan jawabannya. Permasalahan yang 
terkait dengan miamalah dan ibadah terus berkembang. Sedangkan nash-nash yang ada terbatas sehingga dengan metode takhrij ini diharapkan dapat menjawab tantangan zaman dan sebagai pembutkian bahwa syari'at Islam sesuai dengan perubahan zaman dan tempat dalam berbagai dimensi kehidupan. Dr. Ya'qub alBa Husain mendefinisikan takhrij istilah $:^{12}$

"Ilmu yang menghasilkan pengetabuan tentang pendapat para imam dalam masalab- masalah furu'yang tidak ada nashnya dari mereka dengan cara mengbubungkannya dengan bukum yang serupa ketika keduanya memiliki illat bukum yang sama. Bisa juga dengan menselarakannya dalam keumuman pernyataan atau pemahaman keduanya, atau mengambilnya dari perbuatannya atau taqrirny taqrir sang imam.”

Definisi lainnya adalah : "Ilmu dalam memahami pendapat para imam mazhab dalam permasalahan yang baru yang telah terjadi dengan memperluas cakupan bukumnya dalam perkara yang serupa dan illat yang sama dari berbagai cabang fiqh mereka yang sudah mu'tamad (terpercaya)."

\section{Kaidah-Kaidah Takhrij ${ }^{13}$}

1. Takhrij tidak dapat dilakukan apabila nash syar'i didapatkan secara nyata yang terdiri dari nash Alquran, Sunnah. ${ }^{14}$ Kaidah ini adalah kaidah yang penting dalam melakukan takbrij nash-nash mazhab yang mendahulukan sumber yang mu'tabar dan menghabiskan dahulu dalam menggali sumber utama yaitu Alquran, al-Hadits serta ijma'. Imam Syah Waliyullah al-Dahlawi : "Siapa yang ingin mentakhrij maka ia tidak boleh menyalahi sunnah atau mengeluarkan pendapat pada masalah yang ada hadisnya...juga tidak. boleh menolak hadis atan atsar yang sesuai dengan pendapat suatu kaum karena adanya kaidah yang dia takhrij bersama pengikutnya."

2. Seorang pentakhrij hendaknya menguasai secara menyeluruh kaidah-kaidah dan furu' mazhab. Takbrij yang dilakukan oleh seorang faqih tidak sah apabila ia tidak mengetahui kaidah dan ushul mazhab. ${ }^{16}$ Berkata Ibn Shalah : "Mujtahid dalam maz̧hab al-Syafii misalnya, artinya mujtahid takbrij, harus menguasai kaidahkaidah maz̧habnya yang dipakai dalam praktek qiyas dan dan tatacara penerapannya."

${ }^{12}$ Syaikh Ya'qub al-Ba Husain, Al-Takhrij Inda al-Fuqoha' Wa al-Ushuliyin, h. 178-179.

${ }^{13}$ Ibnu Amir al-Haj Ibnu Amir wa al-Haj, At-Taqrir Wa Tabbir (Kairo: Maktabah anNasr, 2014), h. 155-57.

${ }^{14}$ Abdullatif Hidayah Abdul Latif Hidayah, Nawazil Fiqhiyah Fi Al-Amal al-Qadha'i alMagbribi (Rabath: Maktabah Rabath, 2017), h. 319.

${ }^{15}$ Syaikh Wali Allah ad-Dahlawi, al-Inshaf Fi Bayan Asbab al-Ikbtilaf, Ditahqiq Oleh Abd al-Fattah Abu Ghadah, 2: h. 62-63.

16 Ibnu Taimiyah Ibnu Taimiyah, Majmu' al-Fatawa, vol. 30 (Kairo: Dar al-Hadits, 1988), h. 257. 
Imam al-Qarafi berkata : "Seorang mufti tidak boleb mentakhrij suatu pendapat yang tidak ada nashnya dari pendapat yang ada nashnya kecuali ia sudah sangat menguasai kaidah-kaidah mar.habnya dan kaidah ijma'..."

3. Seorang mukharij haruslah menguasai ilmu ushul fikih secara mendalam dan telah terbiasa mempraktikkan qiyas sehingga dapat menghasilkan hukum yang benar dan sesuai dengan mazhab. Ia harus mengetahui ushul fikih secara umum dan qiyas khususnya. Kaidah ini mendorong Imam al-Qarafi melarang mukharij berfatwa bila ia tidak dibekali ushul fikih. Ia berkata : "orang yang tidak menguasai ushul fikih maka ia tidak diperbolebkan berfatwa, karena pastilah ia tidak mengetabui kaidah-kaidah furu', mukhasas, muqayad menurut perbedaan bentukbentuknya...". Ia juga berkata :" Hendaklah Orang yang tidak menguasai ushul figh tidak mentakbrij furu' atau permasalaban yang berasal dari ushul mąhabnya serta berbagai hal yang dinukilkan darinya, walaupun ia banyak menghafal nash-nash syariah dari kitab dan sunnah serta perkataan, pendapat dan bukum yang berasal dari sababat. Begitu juga orang yang tidak mengetabui ushul figh, haram atasnya melakukan qiyas dan mentakhrij dari masalah yang ada nashnya, babkan haram baginya melakukan istinbath bukum dari nash-nash syariah karena menggali furu' diperlukan bekal ushul figh yang dalam, baik ia seorang mujtabid dalam tingkat tertentu maupun muqalid.

4. Mukbarrij harus mempunyai kemampuan untuk mendapatkan sumber yang terkait antara furu' dengan ushul mazhabnya. Hal yang senada dikatakan oleh al-Amidi : "pendapat yang terpercaya adalah seorang mujtiahid mazhbab boleh menggali atau memunculkan pendapat mujtahid mutlak yang diikutinya, itulab bedanya ia dengan orang yang awam.

5. Mukharrij menguasai faktor-faktor eksternal terhadap hukum dan furu'-furu' fikih diantara cabang-cabang. Ini kaidah penting juga dalam praktik takhrij, dimana seorang pentakhrij mewaspadai adanya faktor-faktor yang merusak keabsahan takhrij atau yang akan merusak suatu hukum dalam bentuk nasakh, takbshis, dan taqyid, atau menafikan tujuan takbrij dan menyempurnakan pengetahuan faktor-faktor tersebut hendaklah dengan merujuk pembahasan ushul fikih.

6. Seorang alim hendaknya dapat memahami perbedaan furu' di antara cabang (furu') peristiwa atau permasalahan yang terjadi dengan furu' yang akan di takhrij baik dalam hukum maupun maqhasid-nya. Seperti yang dikatakan oleh Syaikh al-Islam Ibnu Taimiyah: "persyaratan takhrij adalab antara kedua permasalahan harus sama karakternya dan tidak ada pembeda diantara keduanya. Takbrij yang dilakukan terhadap pendapat para imam mazhab haruslah dari sumber yang diakui oleh para ulama".

Ada beberapa sumber pendapat imam-imam mazhab antara lain :

1. Nash imam dan yang semisalnya, ada dua cara untuk mengetahuinya:

a. Dari buku karya para imam yang dinisbahkan kepada mereka dan segala bentuk karya mereka yang diakui secara mutawatir dan shahih, seperti al- 
Muwattho' yang disusun oleh Imam Malik dan al-Umm karya Imam alSyafii, dan yang lainnya.

b. Kutipan pendapat mereka oleh para pengikutnya dalam berbagai masalah yang berbeda.

2. Pemahaman nash imam, yaitu mentakhrij berdasarkan pemahaman perkataannya dalam dilalah lafaz yang wadh'i atau iltizami.

3. Kebiasaan dan perbuatan yang dilakukan oleh para imam, perbuatan tersebut terkait dengan hukum, diperbolehkan, diwajibkan, dimakruhkan dan yang dilarang.

4. Persetujuan (Taqrir) Imam, yaitu tidak adanya sanggahan dari mujtahid terhadap apa yang dilakukan dalam pengetahuannya atau langsung dihadapannya seperti fatwa yang berasal dari orang lain tentang berbagai masalah dan hal ini dibenarkan oleh sang imam.

5. Hadis mutawattir dan sahih.

Ilmu Takbrij al-Furu' atas al-Ushul, berasal dari empat ilmu yaitu: ${ }^{17}$

1. Ilmu Ushul al-Fiqh sebagai dasar utama

2. Ilmu Bahasa Arab yang terkait dengan pembahasan Ushul Fiqh seperti dilalah (petunjuk) lafaz dan qawaid al-Lughawiah

3. Ilmu Fikih, dengan menganalisis furu' fikih akan mendapatkan kesimpulan yang dipandu oleh kaidah ushul fiqh mazhabnya.

4. Ilmu al-Khilaf, karena timbulnya ilmu takhrij didasarkan kepada keinginan mengikuti para imam dan menerangkan kebenaran furu' fiqh mazhab mereka yang berasal dari kaidah dan ushul yang mu'tabar dan mereka konsekuen kaidah tersebut.

Secara ringkas proses penetapan hukum dalam sebuah permasalahan dapat dilihat dari penjelasan berikut:

Seorang faqih apabila berijtihad dalam mentakhrij, ${ }_{18}^{8}$ perkataan para imam mazhab dan telah banyak pengalamannya dalam jenis ijtihad yang seperti ini, maka dia akan lebih mampu dalam melakukan istinbath hukum dalam perkara hukum kontemporer yang didapatkannya. Ia tentunya lebih mengetahui pendapat para Imam yang lebih kuat dan lebih rajih. Maka ia berpegang kepada pendapat yang rajih berdasarkan sumbernya dan dalilnya. Ia akan mudah dalam mengeluarkan fatwa dan mendapatkan jalan pintas walaupun ia belum lagi

\footnotetext{
${ }^{17}$ Jamaluddin Mahmud Jamaluddin Mahmud, Ijtihad Jama'i Fi Mamlakah al-Arabiyah asSu'udiyah (Abu Dhabi: Jami’ah Imarat, n.d.), h. 392-395.

18 Seorang mujtahid mazhab menganalisis masalah yang tidak ada nashnya lalu mengqiyaskannya kepada masalah yang ada nashnya dalam suatu mazhab)
} 
mencapai derajat mujtabid mustaqil. Imam bin Shalah mengatakan" dibolehkan bagi mukharrij, untuk berfatwa apabila tidak ada hukum yang ada nashnya tentang perkara tersebut dari Imamnya, yang telah ditakhrij menurut mazhabnya. Ini adalah perbuatan yang benar. Daripada menunggu waktu yang lama. Seorang mujtahid dalam mazhab as-Syafi'i misalnya, menguasai qaidah-qaidah mazhabnya, terlatih dalam qiyas dan standar prosedur, ia lebih mampu melakukan penyamaan perkara yang ada nasnya dengan yang tidak ada nashnya sejalan dengan qaidah mazhab yang dianutnya. Sebagaimana kedudukan mujtahid mustaqil dalam melakukan proses qiyas (menyamakan perkara yang mempunyai nash dengan yang tidak karena ada persamaanan dalam illat). Apabila seorang mujtahid mendapatkan qaidah-qaidah dan ketetapan yang sudah baku yang berasal dari para imam dalam mazhabnya sedangkan ia belum mendapatkannya melalui dalil-dalil syara' secara tersendiri, kemudian ia melakukan takhrij berdasarkan kaidah yang berasal dari imamnya. Berarti ia berpegang kepada perkataan dan kaidah imam bukan sebagai seorang yang berijtihad bebas. Melakukan takbrij lebih mudah dari pada melakukan istinbath bukum bagi seorang mujtahid mustaqil. Berdasarkan ini kebanyakan para ahli ushul membolehkan seorang Mukharij, berfatwa merupakan jenis dari ijtihad yang diakui (معتبر). Tidak ada salahnya kita melihat bagaimana seorang melakukan takhrij, serta menerangkan cara dan metode yang ditempuhnya dalam memecahkan perkara-perkara kontemporer yang muncul. ${ }^{19}$

Metode yang paling penting dalam takhrij adalah qiyas, sedangkan penukilan, sedangkan menukilkan dan takhrij serta mengikuti mazhab imam, ia merupakan bagian atau cabang dari metode qiyas. Metode ini sedikit digunakan dalam melakukan takhrij terhadap perkataan para imam melalui qiyas atas perkataan tersebut. Oleh karena itu kita mencukupkan saja penjelasan metode ini yang merupakan bagian dari takhrij sendiri dan tidak membahas metodemetode lain. ${ }^{20}$

\section{Takhrij dengan Qiyas}

Jumhur fuqaha beranggapan metode ini adalah cara paling penting untuk dijadikan media dalam mengenal hukum syara' yang tidak ada nasnya sama sekali. Mereka menganggap metode ini adalah penyingkap hukum yang tidak ada lafaz/dalil apapun yang membahasnya atau menetapkannya. Keterangan tentang umum dan khususnya hukum dalam permasalahan pun tidak ada, maka dalam keadaan seperti ini qiyas sangat diperlukan. Hukum takhrij beragam sesuai

${ }_{19}$ Abdu Rabb an-Nabi Abdu Rabb an-Nabi, Dustur Al-Ulama', vol. 2 (Beirut, Lebanon: Dar Al-Kutub Al-Ilmiyah, 2010), h.192.

${ }^{20}$ Masfar bin Ali bin Muhammad al-Qahtani Masfar bin Ali bin Muhammad alQahtani, Manhaj Istikhraj Al-Ahkam al-Fiqhiyah Li an-Nawazil al-Mu'ashirah, vol. 2 (Makkah: Universitas Umm al-Quta, n.d.), h. 556. 
dengan jenis qiyas yang digunakan dalam proses takbrij tersebut. Kita akan membahas tiga jenis, yang terpenting adalah: $:^{21}$

1. Apa yang telah diputuskan bahwa tidak terdapat perbedaan:

Jumhur Ushuli berpendapat apabila telah diputuskan bahwa tidak ada perbedaan antara masalah yang tidak ada nashnya dengan permasalahan yang sama yang dalamnya terdapat pendapat imam. Dalam hal ini boleh menisbahkan hukumnya kepada pendapat imam, dan hukum tersebut dikaitkan dengan mazhabnya. Akan tetapi hendaklah seorang mujtahid mengkonfirmasi dengan pasti bahwa permasalahan yang akan diputuskan hukumnya tidak ada perbedaan sama sekali dengan hukum yang ada pendapat imam dalamnya. Dengan kata lain adanya persamaan yang sempurna dalam kedua permasalahan tersebut. Pendapat inilah yang dipilih oleh Abu Husain al-Basri, Imam Haramain al-Juwaini, Abu Ishaq as-Syirazi, Ibnu Qudamah, at-Thufi, dan para ahli Ushul lainnya.

2. Jumhur Ushuli membolehkan untuk mentakhrij illat yang ada dalam Nash Imam, atau apa yang diisyaratkan oleh imam itu sendiri, pendapat ini sesuai dengan Hasan bin Hamid ${ }^{22}$, dan Abu Husain al-Basri, Abu al-Khatab, Ibnu Qudamah, Ibn Taimiyah. Karena barangsiapa yang membolehkan takhrij secara mutlak maka ia akan membolehkan juga takhrij atas nash-nash yang illatnya telah diisyaratkan oleh imam. Hal inilah yang menjadi prioritas utama karena telah ada petunjuk langsung dari sang imam. Sebagian fuqaha yang membolehkan takhrij seperti ini, akan tetapi mereka tidak membolehkan untuk menisbahkan hasilnya kepada pendapat imam secara langsung. Walaupun begitu mereka masih menganjurkan untuk mengatakan, "hal ini sesuai dengan ketentuan mazhabnya". Sebagaimana Ibnu Abidin Rahimahullah membolehkan hal tersebut. Sedangkan Imam Abu Ishaq asSyirazi Rahumahullah, membantah kebenaran pendapat itu, ia mengatakan "perkataan seorang manusia haruslah ada buktinya, atau ada sesuatu bukti yang sama kedudukannya dengan nash sebagai bukti perkataannya. Kalau tidak ada dalil yang membuktikannya maka tidaklah sah mengatakan itu pendapatnya. Oleh karena itu Imam as-Syafi'iy tidak menisbahkan pendapat apapun kepada orang yang diam (tidak menyatakan pendapat). ${ }^{23}$

3. Illat yang didapatkan melalui cara isthinbat

Melakukan takbrij atas mazhab imam dengan qiyas yang diistinbatkan dengan illat kelihatannya lebih rumit daripada cara terdahulu, ulama pun berbeda pendapat tentang kebolehan melakukan cara ini. Yaitu:

${ }^{21}$ Masfar bin Ali bin Muhammad al-Qahtani, Jilid 2: h. 557-58.

${ }^{22}$ Hasan bin Hamid adalah Imam Mazhab Hambali, guru Qadi Abu Ya'la, mendengar banyak riwayat dari Imam Ahmad bin Hanbal melalui karya-karyanya, al-Jami' fi al-Mazhab, Ktiab fi Hushul al-Fiqh, dan dalam Ushuluddin,. Ia wafat pada tahun $403 \mathrm{H}$.

${ }^{23}$ Ibnu Abidin Ibnu Abidin, Radd Al-Mukbtar Ala Dur al-Mukbtar (Beirut, Lebanon: Dar Ihya at-Turats al-Arabi, 1990), h. 161. 
a. Pendapat pertama mengatakan tidak boleh menisbahkan pendapat hasil istinbat illat kepada imam. Yang berpendapat seperti ini adalah Abu Bakar Khilal Rahimahullah, Abu Bakar Abd al-Aziz al-Baghwi yang dikenal sebagai Hamba Khilal Rahimahullah, dan sebagian para Ulama Hanbali. Pendapat ini adalah zahir dari perkataan Abu Husain al-Basri, Abu Ishaq as-Syirazi.

b. Sesuatu yang diqiyaskan terhadap perkataan imam dianggap mazhabnya adalah sah untuk menisbahkan hasil istinbat qiyas tersebut kepadanya. Dr. AlBahusain telah menasabkan kepada jumhur ulama, yang juga merupakan ikhtiar Abu Bakar al-Atsram, al-Kharqi, sedangkan Imam Juwaini dan Ibnu Shalah cenderung kepada pendapat tersebut. Orang-orang yang berpendapat seperti itu dengan berbagai dalil dan alasan;

1) Qiyas bukanlah mantuq (makna yang diambil dari lafaz/operatif) dan tidak dinisbahkan kepada seseorang sesuatu yang tidak pernah dikatakannya atau dilafazkannya. Dalam kaidah dikatakan, ينسب لساكت قل tidak dinisbahkan kepada orang yang diam pendapat apapun.

2) Penisbahan terhadap mazhab imam dengan jalan qiyas tidak dapat menyatukan (memberikan batasan) dengan pasti

3) Kemiripan yang sempurna terhadap kedua permasalahan, boleh jadi tak terlihat pada waktu itu bagi sebagian mujtahid, akan tetapi boleh jadi bagi sebagian mujthahid lagi dapat menemukan perbedaan antara kedua masalah tersebut.

Dalil Kelompok yang tidak setuju dengan pendapat ini telah dibahas sebagai berikut:

a. Mereka mengatakan qiyas bukanlah jenis dari perkataan, dan tidak dinisbahkan perkataan kepada orang yang diam. Hal ini tidak sama dengan illat yang dikeluarkan dari nash. Karena penunjukan illat dalam sebuah nash berkedudukan sama dengan penunjukan nash terhadap hukum (penentuan hukum dengan menggunakan nash yang jelas). Hal ini tidak sama dengan diamnya seseorang dalam sebuah hukum yang harus diputuskan, bahkan penunjukan illat dalam sebuah nash sama kedudukannya dengan mantuq (makna tersurat/tertera pada nash dengan jelas/operatif).

b. Pendapat orang-orang yang tidak setuju dalam penetapan mazhab imam dengan jalan qiyas tidak punya batasan yang pasti (بغير جامع), membutuhkan penjelasan lagi. Sebuah qiyas haruslah mengumpulkan dan membatasi illatnya, kalau tidak terdapat pengumpulan dan pembatasan mana mungkin qiyas bisa dilakukan.

c. Pendapat yang mengatakan terdapat perbedaan antara permasalahan yang ada nasnya dengan permasalahan yang akan ditakhrij (disesuaikan karena ada persamaan illat) dalam istinbat illat, akan tetapi para ulama telah memberikan persyaratan tentang sahnya takhrij yaitu adanya persamaan yang sempurna dan tidak ada perbedaan sama sekali. 
Adapun dalil dari pendapat kedua $:^{24}$

a. Qiyas yang dikeluarkan (المخرّج) terhadap nash-nash imam diqiyaskan pada mujtahid mutlaq dalam mengisitnbatkan hukum syara' dengan qiyas terhadap nash-nash syara' (perbandingan qiyas dengan nash-nash syara' dengan qiyas terhadap nash-nash imam). Bahkan seorang mukharij lebih mampu melakukan penyamaan (الحاق) dengan ushul mazhab dari seorang mujtahid dalam melakukan qiyas dengan menggunakan dasar-dasar syari'at. Karena mazhab-mazhab telah membentangkan dan mengatur sistim yang harus dilalui dalam proses qiyas serta faktor-faktor penyebabnya. Mudah bagi mukhrij melakukannya apa yang tidak mudah melakukannya bagi mujtahid mutlak.

b. Buku-buku yang disusun fuqaha berdiri diatas takhrij, karya-karya para fuqaha telah menjadi saksi terhadap takhrij.

c. Kalau tidak dilakukan qiyas terhadap perkataan para imam maka banyak dari permasalahan-permasalahan hukum yang terjadi menjadi terbengkalai. Hal ini tidak bisa dibiarkan begitu saja.

Bantahan terhadap kelompok yang membolehkan: ${ }^{25}$

a. Menjadikan nash-nash imam sederajat dengan nash-nash syara' dan menyamakan mujtahid dengan Syari' (Pencipta Hukum), tidak bisa diterima secara mutlak. Karena syari' dijadikan ibadah dengan hanya membaca nashnashnya. Dijadikan ibadah dalam melakukan istinbat hukum apabila dalam nash-nashnya didapatkan illatnya dalam suatu permasalahan. Pada permasalahan apapun apabila didapatkan persamaan illat kecuali telah didapatkan dalil yang menghususkannya untuk tidak dapat dijadikan dasar sebuah hukum. Perkara ini tidak ada atau tidak terealisasi dalam jiwa mujtahid yang hanya manusia biasa.

b. Pekerjaan para fuqaha yang seperti ini, merupakan bagian dari takhrij yang memberikan kekuatan apapun terhadap dalil. Pertikaian antara para ulama terjadi kebanyakan disebabkan perbedaan persepsi dalam kebenaran takhrij yang dilakukan ketika dijadikan dalil atau dipakai untuk menetapkan sebuah hukum dalam mazhab

c. Ketiadaan hukum bagi peristiwa-peristiwa kontemporer yang terjadi tidak selalu dapat dipecahkan dengan takhrij atas illat-illat dan perkataan para imam dan mengistinbatkan hukum dari perkataan serta pendapat imam tersebut. Pemecahannya adalah kembali kepada sumber asli dengan berijtihad dari dalil dalil dan qaidah-qaidah secara langsung, dengan melakukan persiapan dan pengadaan orang sanggup melakukan ijtihad tersebut.

${ }^{24}$ al-Warqiyah Abd ar-Raziq, Ad-Dhawabit at-Tanzili (Beirut, Lebanon: Dar al-Ma'rifah, 2013), h. 25-29.

${ }^{25}$ Ibnu Nujaim Ibnu Nujaim, Al-Babr Raiq Syarah Kanz, Ad-Daqaiq (Beirut, Lebanon: Dar al-Kitab al-Islami, 2015), h. 216. 


\section{Tarjih:}

Telah dapat dilihat apa yang telah dipaparkan, berbagai dalil dari pihak yang melarang dan membolehkan takhrij. Pada dasarnya ijtihad dan istinbat mempergunakan dalil syara'. Pembolehan takhrij atas perkataan para imam merupakan pengecualian khusus yang diperbolehkan oleh para mujtahid mazhab-mazhab. Hal ini disebabkan sedikitnya mujtahid mutlak atau mustaqil, melemahlah kemampuan untuk beristinbat dari dalil syara' secara langsung. Takhrij ini diperbolehkan karena banyaknya peristiwa-peristiwa yang membutuhkan kepastian hukum yang terjadi, yang sulit untuk dicari pemecahannya dari dalil-dalil syara' secara langsung. Atas dasar ini takhrij diperbolehkan, akan tetapi haruslah dilakukan dengan hati-hati, dalam melakukan takbrij atas perkataan para imam. Hendaklah perkataan imam ini mempunyai dasar syara' pula guna mendukung kebenarannya. Setidaknya terdapat illat yang jelas yang langsung dinyatakan oleh sang imam dalam memutuskan suatu perkara. ${ }^{26}$

5. Takhrij fikih terhadap beberapa kasus kontemporer ${ }^{27}$

a. Asuransi Koperasi (Cooperative Insurance) dan Asurnsi Perdagangan

Asuransi ini adalah asuransi yang beranggotakan sekelompok orang yang berpotensi menanggung risiko yang sama dan anggotanya membayar jumlah tertentu untuk mendapatkan uang santunan, apabila dikemudian hari salah seorang atau beberapa orang dari anggota asuransi koperasi ini menanggung risiko yang telah diprediksikan. Apabila iuran anggota kurang dari tanggungan musibah atau kerugian yang dibayarkan maka para anggota menambah iuran mereka akan tetapi kalau risiko yang ditanggung menimbulkan biaya yang lebih kecil daripada yang dibayarkan oleh anggota asuransi maka sisa uang mereka dikembalikan. Para anggota asuransi dalam hal ini tidak bertujuan untuk mendapatkan keuntungan akan tetapi untuk meringankan musibah. Asuransi ini sangat jarang dipraktikkan pada zaman sekarang. Sedangkan asuransi perdagangan telah dibahas oleh Ibnu Abidin tentang pengamanan laut (asuransi pelayaran) dan keharaman asuransi yang sudah lama dilakukan oleh Umat Islam. Ahli Fiqh kontemporer berbeda dalam menetapkan hukumnya, karena berbeda dasar takhrij mereka dan tata cara penanganan masalah baru ini, diantara mereka ada yang mengharamkan secara mutlak, ada yang menghalalkan dan ada juga yang menghalakan beberapa jenis asuransi. Yang mengharamkan berdasarkan takhrij asuransi diqiyaskan kepada perjudian yang bermain dengan nasib manusia dan benda yang penuh dengan spekulasi tinggi. Ditambah lagi asuransi tersebut termasuk gharar atau transaksi gharar sebab berupa akad spekulatif yang juga mengandung riba. Sebagian lagi membolehkan seperti

${ }^{26}$ Masfar bin Ali bin Muhammad al-Qahtani, Manhaj Istikhraj Al-Abkam al-Fiqhiyah Li an-Nawazil al-Mu'ashirah, Jilid 2: h. 116.

${ }^{27}$ Masfar bin Ali bin Muhammad al-Qahtani, Jilid 2: h. 562-64. 
Abdul Wahab Khalaf, Ali Khafif dan Syaikh Mustafa Zarqa. Mereka menisbahkan asuransi perdagangan kepada maslahah al-mursalah yang tidak ada nash yang mengharamkan asuransi tersebut. Asuransi juga dapat diqiyaskan kepada aqilah (keluarga penanggung diyat) yang menanggung diyat pembunuhan tidak sengaja atau semi sengaja. Aqilah ini yang membayarkan diyat pelaku pembunuhan tersebut dan mirip dengan asuransi yang juga sama dengan akad perwalian tersebut. ${ }^{28}$ Sedangkan sebagian lagi melarang asuransi jiwa dan membolehkan asuransi benda.

b. Hak Kekayaan Intelektual (Karya ilmiah, penerbitan dan distribusi/penjualan)

Hak-hak ini belum pernah ada hukumnya di kalangan fuqoha' klasik. Pada masa lalu pengulangan hasil karya bukan sebuah larangan, akan tetapi setelah munculnya mesin cetak di Eropa telah membuahkan keuntungan luar biasa bagi penerbit sedangkan si pemilik karya tidak banyak mendapatkan keuntungan materil. ${ }^{29}$ Para fuqaha ada yang mentakhrijnya dengan mengqiyaskan kepada pendapat dalam Fiqh Hanafi tentang (Nuzul an Warha'if bi Mal). ${ }^{3}$

Di antara mereka ada pula yang tidak menetapkan hak ini dengan mentakhrijnya kepada kemaslahatan menyebarkan pemikiran Islam dan melepaskannya dari seluruh pembatasan-pembatasan. ${ }^{31}$ Sebagian lagi ada yang memberikan hak tersebut dalam jangka waktu tertentu dan setelah beberapa tahun berlalu hak itu menjadi milik orang banyak demi menyebarkan ilmu pengetahuan yang tidak boleh disembunyikan.

c. Pentakhrijan pendapat Imam Syafi'iy shalat al-Wusta adalah Subuh, akan tetapi terdapat hadits yang sahih yang mengatakan shalat al-Wusta adalah shalat Ashar, sedangkan kaidah mazhab adalah mengikuti Hadits ( إذا صح الحديث فهو مذهبي (ف). Maka jadilah sebuah keputusan mazhab bahwa shalat al-Wusta itu adalah shalat Ashar dan pengarang buk al-Hawi mengatakan tidak ada dua pendapat seperti yang dikatakan oleh para sahabat kami. ${ }^{32}$

28 Meirison Meirison, "Riba and Justification in Practice in Scholars' Views," TRANSFORMATIF 2, no. 1 (September 20, 2018): 348, https://doi.org/10.23971/tf.v2i1.922.

${ }^{29}$ Meirison Meirison, "Implementasi Tanqih Al-Manath Dalam Penerapan Hukum," Niæ̧ham Journal of Islamic Studies; Vol 2 No 1 (2014): Mą̧ab Hukum Islam Di Indonesia, September 25, 2017, http://e-journal.metrouniv.ac.id/index.php/nizham/article/view/868.

30 Abdullah bin Ibrahim Musa, Al-Mu'awadhah Ala al-Huquq Ad-Dhawabit Wa Tatbiquba (Kairo: Syabab al-Azhar, 1988), h. 177.

${ }^{11}$ Kamaluddin Muhammad Muhammad Abdul Wahid, Fath Al-Qadir Ala al-Hidayah (Beirut, Lebanon: Dar al-Fikr, 1990), h. 257.

32 al-Mawardi al-Mawardi, Al-Hawi al-Kabir, vol. 2 (Beirut, Lebanon: Maktabah atTurats al-Arabi, 1988), h. 321. 


\section{Penutup}

Dapat diambil kesimpulan sesuai dengan pembahasan diatas, bahwa Ilmu Takbrij al-Furu' 'ala al-Ushul adalah ilmu yang menerangkan kaidah ushuliyah yang dibangun oleh para imam, salah satunya adalah furu' dalam fatwa, mengikatnya dan menyamakan dengan perkara yang sejenis dan tidak pernah difatwakan. Ruang lingkup ilmu takbrij al-furu' 'ala al-ushul adalah qawa'id ushuliyah dan furu' fiqhiyah, dari konstruksi yang kedua atas yang pertama (penyamaan). Ilmu Takbrij al-Furu' 'ala al-Ushul, mengenal konstruksi fikih yang dibangun oleh para imam, dan mengeluarkan hukum yang tidak ada nashnya, menumbuhkan kemampuan dan bakat dalam ilmu fikih, menerapkan ilmu ushul fikih dalam praktik nyata di lapangan, maka didapatkanlah hubungan antara fikih dan ushulnya. Kemudian menerangkan perbedaan pendapat ilmiah dan metode serta kaidah dalam istinbath. Hanya saja perkembangan ilmu ini sangat tergantung praktik hukum Islam yang diterapkan di lapangan sehingga terjadilah hubungan interaksi antara teori dan praktik. Sebagian ulama mengatakan bahwa perbuatan imam semata tidak dianggap sebagai bagian dari mazhab. Imam bukanlah seorang yang ma'sum (terlindung dari dosa), dan tidak bisa diqiyaskan kepada Nabi Muhammad S.A.W. Nabi terlindung dari kesalahan dengan adanya wahyu. Perbuatan imam penuh dengan spekulasi adakalanya benar dan adakalanya salah. Oleh karena ini seluruh penafsiran yang berasal dari mazhab bersifat zani yang tidak mengikat bagi seseorang untuk mengikutinya. Hal ini berbeda statusnya dengan kesepakatan imam dan perkataannya yang berasal dari pemikiran dan kesadaran penuh dalam melakukannya.

\section{Daftar Pustaka}

Abd al-Qadir ibn Ahmad ibn Badran, Abd al-Qadir ibn Ahmad ibn Badran. alMadkhal ila Marhab al-Imam Ahmad. Kairo: Maktabah Ibnu Taimiyah, 1977.

Abdu Rabb an-Nabi, Abdu Rabb an-Nabi. Dustur Al-Ulama'. Vol. 2. 2 vols. Beirut, Lebanon: Dar Al-Kutub Al-Ilmiyah, 2010.

Abdul Latif Hidayah, Abdullatif Hidayah. Nawazil Fiqhiyah Fi Al-Amal al-Qadha'i al-Maghribi. Rabath: Maktabah Rabath, 2017.

Abdullah bin Ibrahim Musa. Al-Mu'awadhah Ala al-Huquq Ad-Dhawabit Wa Tatbiquba. Kairo: Syabab al-Azhar, 1988.

Ahmad Ibn Abdul Haliim, Ibnu Taiymiyah. Al-Musawwidah, Mubaqqiq : Mubammad Mubyi al-Din Abd al-Hamid. Beirut: Dar al-Kutub, 1987.

Alawi al-Saqaf, Alawi al-Saqaf. Al-Fawaid al-Makiyah. I. Riyadh: Maktabah alRusyd, 1404. 
al-Warqiyah Abd ar-Raziq. Ad-Dhawabit at-Tanzili. Beirut, Lebanon: Dar alMa'rifah, 2013.

Ibnu Abidin, Ibnu Abidin. Radd Al-Mukbtar Ala Dur al-Mukhtar. Beirut, Lebanon: Dar Ihya at-Turats al-Arabi, 1990.

Ibnu Amir wa al-Haj, Ibnu Amir al-Haj. At-Taqrir Wa Tabbir. Kairo: Maktabah an-Nasr, 2014.

Ibnu Farhun al-Maliki, Ibnu Farhun al-Maliki. Kasyf Al-Naqab al- Hajib Fi Mushthalah Ibn al-Hajib, Ditahqiq Oleb Hamzah Abu Faris Dan Abd alSalam al-Syarif. Rabath: Dar al-Gharb al-Islami, 1990.

Ibnu Nujaim, Ibnu Nujaim. Al-Babr Raiq Syarah Kanz, Ad-Daqaiq. Beirut, Lebanon: Dar al-Kitab al-Islami, 2015.

Ibnu Taimiyah, Ibnu Taimiyah. Majmu' al-Fatawa. Vol. 30.30 vols. Kairo: Dar alHadits, 1988.

Jamaluddin Mahmud, Jamaluddin Mahmud. Ijtihad Jama’i Fi Mamlakah alArabiyah as-Su'udiyah. Abu Dhabi: Jami'ah Imarat, n.d.

Masfar bin Ali bin Muhammad al-Qahtani, Masfar bin Ali bin Muhammad alQahtani. Manhaj Istikhraj Al-Ahkam al-Fiqbiyah $\mathrm{Li}$ an-Nawazil alMu'ashirah. Vol. 2. 2 vols. Makkah: Universitas Umm al-Quta, n.d.

Mawardi, al-Mawardi al-. Al-Hawi al-Kabir. Vol. 2. Beirut, Lebanon: Maktabah at-Turats al-Arabi, 1988.

Meirison, Meirison. "Implementasi Tanqih Al-Manath Dalam Penerapan Hukum." Nizham Journal of Islamic Studies; Vol 2 No 1 (2014): Mą̧bab Hukum Islam Di Indonesia, September 25, 2017. http://ejournal.metrouniv.ac.id/index.php/nizham/article/view/868.

- "Riba and Justification in Practice in Scholars' Views." TRANSFORMATIF 2, no. 1 (September 20, 2018): 348. https://doi.org/10.23971/tf.v2i1.922.

Muhammad Abdul Wahid, Kamaluddin Muhammad. Fath Al-Qadir Ala alHidayah. Beirut, Lebanon: Dar al-Fikr, 1990.

Muhammad Riyadh, Muhammad Riyadh. Usbul Al-Fatwa Wa al-Qadha' Fi alMą̧bab al-Maliki. Maroko: Matba'ah al-Najah, 1416.

Musfir bin Ali bin Muhammad, Musfir bin Ali bin Muhammad. Manbaj Istinbath Abkam Al-Nawazil al-Fiqhiyah al-Mu'ashirah. Jeddah: Dar al-Andalus alKhudhoro', 2003.

Sa'ad al-Syatari, Sa'ad al-Syatari. Al-Takbrij Baina al-Ushul Wa al-Furu. Kairo: Dar al-Hadits, 1989. 
Sulaiman Majid, Sulaiman Majid. Takbrij Furu' Ala al-Ushul. Kairo: Maktabah Wafa, n.d.

Syaikh Wali Allah ad-Dahlawi, Syaikh Wali Allah al-Dahlawi. Al-Inshaf Fi Bayan Asbab al-Ikbtilaf, Ditahqiq Oleh Abd al-Fattah Abu Ghadah. Vol. 2. 1 vols. Beirut, Lebanon: Dar al-Kutub Ilmiyah, 1987.

Syaikh Ya'qub al-Ba Husain, Syaikh Ya'qub al-Ba Husain. Al-Takbrij Inda alFuqoha' Wa al-Ushuliyin. Riyadh: Maktabah al-Rusyd, 1414. 